\title{
PROPOSITION OF INTEGRATED ELECTRICAL MECHANISM AND FACIAL PROSTHESIS FOR EYELID MOTION ON PROSTHETIC OCULOPALPEBRAL REHABILITATION: TECHNICAL NOTE
}

\author{
PROPOSTA DE MECANISMO ELÉTRICO INTEGRADO E PRÓTESE FACIAL PARA \\ MOVIMENTAÇÃO DA PÁLPEBRA NA REABILITAÇÃO PROTÉTICA \\ OCULOPALPEBRAL: NOTA TÉCNICA
}

\author{
Livia Morelli VIEIRA ${ }^{1}$; Paulo OGURO² ${ }^{2}$ Reinaldo Brito e DIAS ${ }^{3}$; Marina Leite \\ PIMENTEL $^{4}$; Marcos Ribeiro Pereira BARRETTO ${ }^{5}$; Neide Pena COTO ${ }^{6}$ \\ 1. Master of Department of Maxillofacial Surgery, Prosthetics and Traumatology,School of Dentistry, University of São Paulo, São \\ Paulo, SP, Brazil; 2. Mechanical Engineer of Departament of Mechanical Engineering of Polytechnic School, University of \\ São Paulo, SP, Brazil; 3. Full Professor of Department of Maxillofacial Surgery, Prosthetics and Traumatology, School of \\ Dentistry, University of São Paulo, São Paulo, SP, Brazil; 4. PhD of Department of Maxillofacial Surgery, Prosthetics and \\ Traumatology,University of São Paulo, São Paulo, Brazil; 5. Professor of Department of Mechanical Engineering of Polytechnic \\ School, University of São Paulo, SP, Brazil; 6. Associate Professor of Department of Maxillofacial Surgery, Prosthetics and \\ Traumatology, School of Dentistry, University of São Paulo, São Paulo, SP, Brazil.
}

\begin{abstract}
Surgical reconstruction of large facial defects may not be always possible, therefore extraoral maxillofacial prosthesis is a good restorative option. The oculopalpebral prosthesis has a natural appearance however it can be easily noticed because its eyelids do not move. For esthetic purposes, it is desirable that the prosthetic eyelids open and close synchronously with the contralateral eye, which provides a challenge to the prosthetic reconstruction of the oculopalpebral region. To improve the esthetic outcome, an oculopalpebral prosthesis prototype with mechanical and electric features allowing synchronization of the eyelid motion with the sound eye was planned, designed, and built. An oculopalpebral prosthesis was made in thermoactivated acrylic resin. A gap was created to accommodate an electrical system and allow free motion of a thin eyelid made of silicone attached to the appliance. The movable eyelid was made with medical grade silicone (SILASTIC ${ }^{\circledR}$ MDX4-4210) and connected to an electrical and electronic system responsible to command the opening and closing movements. This mechanical and electrical prototype with the system connected to a sensor, successfully captured the eyelid motion of the contralateral sound eye. The proposed mechanical and electrical system attached to an oculopalpebral prosthesis could successfully establish and synchronize the eyelid movements with the sound eye.
\end{abstract}

KEYWORDS: Oculopalpebral prosthesis. Eyelid motion system. Facial rehabilitation.

\section{INTRODUCTION}

Losses on the oculopalpebral region are always extensive, which imply not only the impairment of the globe of the eye, but also of the surrounding tissues, eyelids, muscles, skin and bone. As shown in Figure 1, these losses cause esthetic, functional, social and psychological implications for the patients ( BRACHA ET al.,2003). The origins of impairments may be due to traumatic, pathological or even congenital contexts (BINDHOO; ARUNA, 2011). Because this type of loss occurs on the facial region, these individuals are submitted to great embarrassment due to compromised esthetics and lack of symmetry. Their rehabilitation represents extreme importance for their wellness. Surgical reconstruction of large facial defects may not be always possible, however, these defects can be restored with facial prosthesis (AHMED et al.,2010; ORLOWKA ET AL.,2001)

Even when the oculopalpebral prosthesis shows a natural appearance, it can be easily noticed due to the lack of both eyelid movements and synchronicity during the opening and closing when compared with the contralateral eye. Therefore, the prosthetic reconstruction is a challenging procedure. ${ }^{3}$ Studies on the Extraoral Maxillofacial Prosthetics area always aim to overcome limitations from the rehabilitation techniques. Hence, this multiple disciplinary approach study was made in cooperation with the Department of Mechanical Engineering at the Polytechnic School of the University of São Paulo to build a mechanical feature to help disguising an oculopalpebral prosthesis. 
This study aimed to improve the esthetic outcome, proposing an oculopalpebral prosthesis prototype with mechanical and electric features allowing synchronization of the eyelid motion with the sound eye.

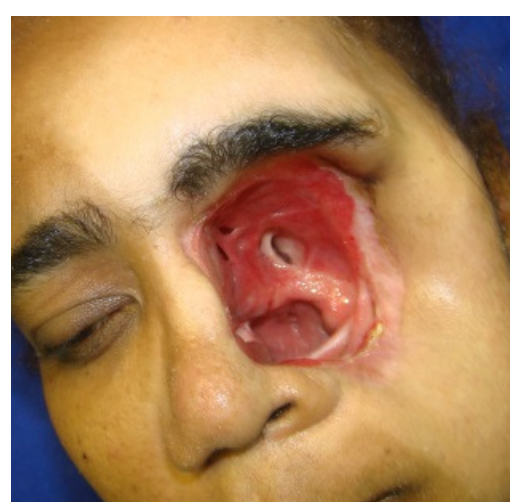

Figure 1. Patient presenting loss in the oculopalpebral region.

\section{MATERIAL AND METHODS}

Due to technological restrictions, many challenges emerged while designing the mechatronical oculopalpebral prosthesis. The most important restriction, and the hardest to overcome, was the available volume for the appliance. Since each different deformity has its own specific volume, the maximum size of the appliance was set to be equivalent to the globe of the eye, allowing it to be employed in most of the oculopalpebral prosthetic rehabilitations. The globe of the eye measures approximately $23.5 \mathrm{~mm}$ in diameter and $6.8 \mathrm{~cm}^{3}$ in volume (BULLING et al., 2011).

Another important restriction to be considered during the design was the total weight of the prosthesis, which must be as light as possible to achieve the correct adhesive retention. A lightweight prosthesis also provides comfort to the patient. For thus, its weight must be similar to the weight of the globe of the eye, which is around 7.5 g. To disguise the prosthesis, the actuator employed on the mechanism had to be able to perform the eyelid motion fast enough, which represents around $150 \mathrm{~ms}$.

The materials employed on the mechanism had to be inert and packed in a capsule with only the motor axis of the eyelids and the power wires exposed, increasing the safety for usage on a delicate facial area.

Based on the specifications above, the following steps were taken:

\section{Selection of the motion detection sensor:}

To identify eyelid motion, the most indicated techniques are electro-oculography, video-oculography and infraredoculography (CASTRO, 2008; CHAU; BETKE, 2005; GUETAL., 2001; KONRATH et al., 2010; KROLAK; STRUMILLO, 2012 ; PARK; AHN; BYUN, 2006; ROUMANAS; FREYMILLER; CHANG, 2002; RYANA et al., 2006). To disguise it, the selected system must be placed on the external surface of the prosthesis, therefore it must be small and noninvasive. Thus, the chosen method was the infrared oculography and for that, an infrared sensor was placed in disguise on eyeglass frame of choice (Figure 2).

Figure 2. Infrared motion capture system

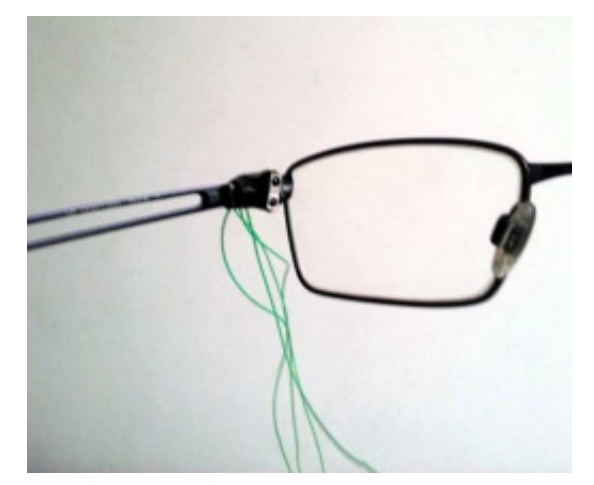




\section{Selection of the eyelid actuator}

The appliance must have had small dimensions taking into consideration the final prosthetic volume, which was limited by the remaining oculopalpebral cavity. Therefore, its final weight was extremely important to ensure comfort for the user (GU et al.,2001). In addition, an electrical actuator was chosen, capable of generating complete open and close movements of the eyelid in approximately $150 \mathrm{~ms}$, disguising the prosthesis.

\section{Control and mechanical design}

The control design consisted of signal conditioning, logical processing and analysis with a microcontroller followed by a motor driver selection. The mechanical design consisted of developing the mechanism responsible to convert the motor movement into the movable eyelid, and in defining both the enclosure and bearings for the motor and the glasses with electrical components and sensor. The electric circuit developed during the control design allowed an eyelid motion in which the open and close movements were synchronized to the contralateral sound eye ${ }^{12}$, as shown in Figure 3. Attached to the appliance, the electric circuit had to follow the proportions described in Figure 4.

Figure 3. Prosthetic eyelid motion mechanism
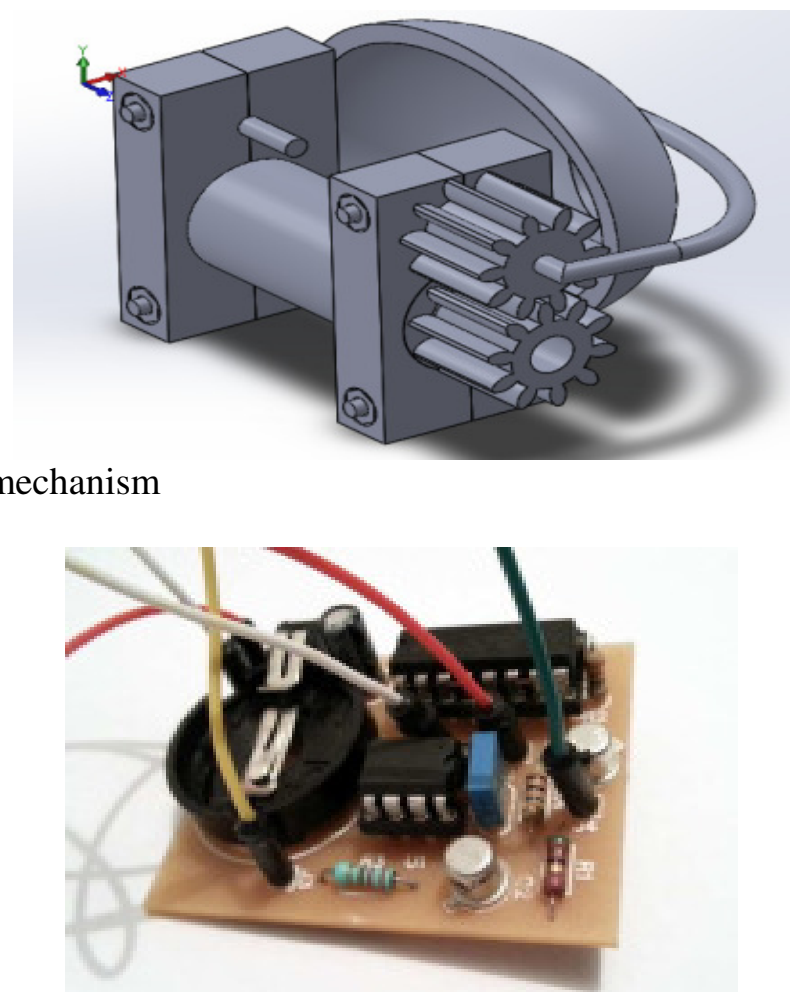

Figure 4. Electronic printed circuit assembled

\section{Prosthesis construction}

The oculopalpebral prosthesis was made in a thermoactivated acrylic resin over a mockup model. The gap to place the electric system was preserved according to the standards for hollow prosthesis, as shown in Figures 5 and 6.

\section{Construction of silicone eyelid attached to the appliance}

A medical grade silicone sheet was made with SILASTIC ${ }^{\circledR}$ MDX4-4210 BioMedical Grade Elastomer (Dow Corning Corporation, Midland MI, USA) and intrinsic pigmentation. A $1 \mathrm{~mm}$ diameter orthodontic wire was modeled according to the patient's curvature of the eyelid.
Subsequently, the silicone was fixed and positioned, allowing free motion for this eyelid to be attached to the electrical and electronic circuit (Figures 2 and 3). 


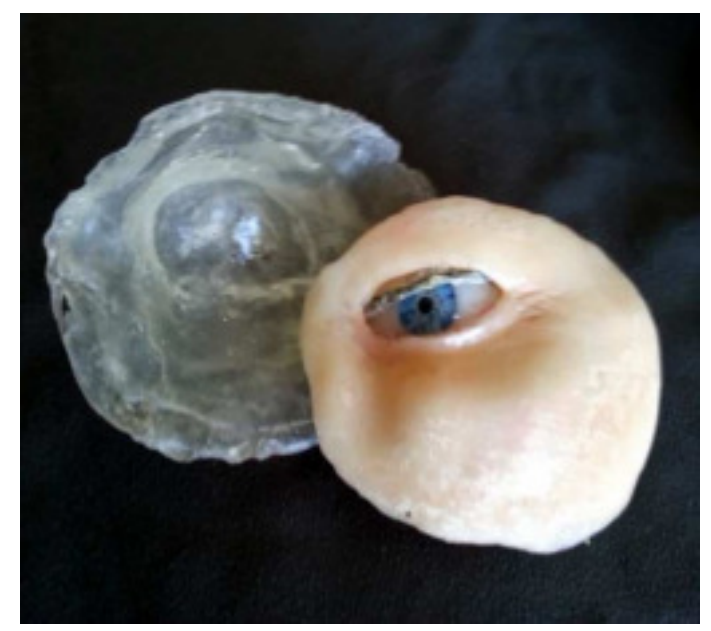

Figure 5. Prosthesis ready to receive electric system

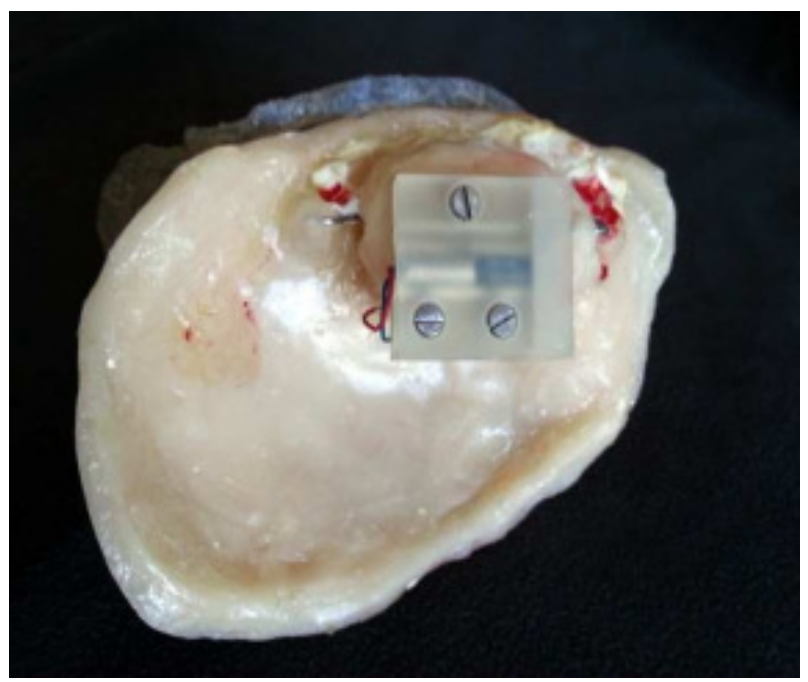

Figure 6. Appliance assembled on prosthesis posterior region

\section{RESULTS AND DISCUSSION}

The oculopalpebral prosthesis with electrical and mechanical features to allow eyelid motion was obtained, as shown in Figure 6.

The attached electric feature allowed a synchronized motion between eyelids from both prosthesis and sound eye. The oculopalpebral prosthesis ready for patient installation (Figure 7) must be worn with the sensor adapted to eyeglass frame (Figure 2).

The proposed mechanism consisted of a DC motor, supported and encapsulated by two pieces, which played the role of motor support and axis bearings of the eyelids. The power was transmitted through gears from the engine to the eyelid axis, aiming to decrease the size of the appliance, since its length was the most critical dimension. The prototype was made with the aid of three-dimensional printers.

The detection system for eyelid motion was made with the aid of infrared oculography. This method provided the best disguise when the appliance was set in a hidden place on the eyeglass frame. Infrared oculography was also easier to perform in comparison with electro-oculography and video-oculography.

The electronic circuit was developed and tested on a breadboard. The system was controlled by the PIC12F675, which is a microcontroller of smaller size. The team had already employed these sorts of controllers in other projects. An $\mathrm{H}$ bridge was employed to promote inversion of engine rotation. Afterwards, a project of printed circuit board was designed to miniaturize the circuit and improve fixation of components. This circuit was inspired from 
the oculopalpebral prosthesis described by KREITLOW ET AL.,2008, which had prosthetic eyelid motion, but without synchronization with the sound eye. The main issues related to the implementation were the total volume and final cost of the prothesis. The engine and the mechanical features required a large prosthetic volume. The final cost of this project may oscillate from US\$ 500.00 to US\$1,000.00 - a value that exceeds the expenses covered by the government for rehabilitation treatment of a patient with facial mutilation in Brazil.

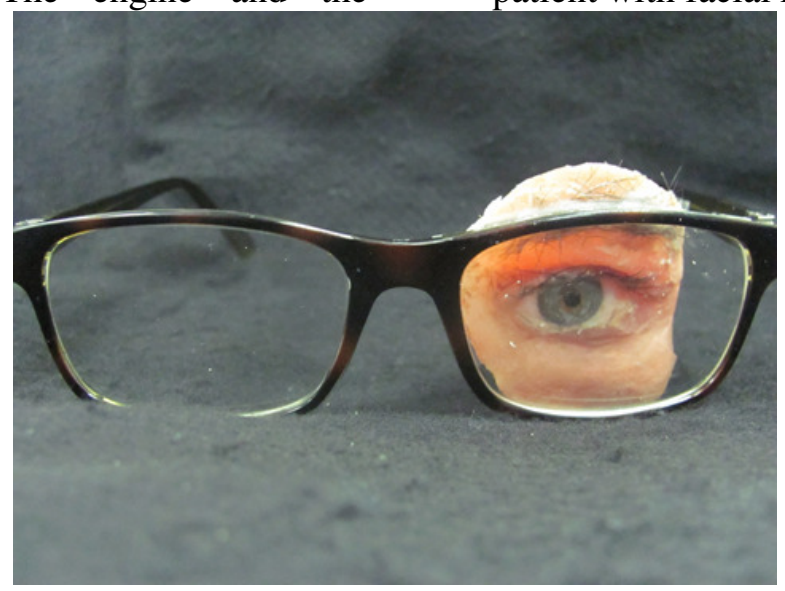

Figure 7. Oculopalpebral prosthesis with the whole system assembled

Konrath et al. 2010 researched several ways to identify eyelid motion and chose the oculography by infrared radiation because it is a noninvasive, simple and discreet procedure. Their mechanism was started by a servomotor and controlled by an (ARDUINO,2014) board. Its final cost was US\$ 500.00 and the engine had a large final volume, limiting its application. The prototype proposed on our research still has limitations such as engine cost, servo motor noise and volume of the appliance. For the moment, our prototype can be applied in large facial losses, but our efforts have been focused in researching ways to overcome these limitations. This appliance is patented under the number BR 1020150066686 at the Brazilian National Institute of Industrial Property (INPI).
This study stimulates the multiprofessional interaction in the search for the return of quality of life and moral uplift of the face mutilated patient, authors show that in several segments the quality of life is a very important item for the wellness of the patient (CÉSAR ET AL.,2016; ALMEIDA ET AL.,2017).

\section{CONCLUSION}

A mechanical and electrical prototype was successfully planned, designed, developed and attached to an oculopalpebral prosthesis. The prototype established and synchronized the eyelid movements of the prosthesis with the contralateral sound eye.

RESUMO: A reconstrução cirúrgica de grandes defeitos faciais pode não ser sempre possível, portanto, a prótese bucomaxilofacial extra-oral é uma boa opção restauradora. A prótese oculopalpebral tem uma aparência natural, mas pode ser facilmente notada pois as pálpebras não se movimentam. Para fins estéticos, é desejável que as pálpebras protéticas se abram e se fechem em sincronia com o olho contralateral, o que representa um desafio para a reconstrução protética da região oculopalpebral. Para melhorar o resultado estético, um protótipo de prótese oculopalpebral com características mecânicas e elétricas permitindo a sincronização do movimento da pálpebra com o olho sadio foi planejado, projetado e construído. Uma prótese oculopalpebral foi confeccionada em resina acrílica termoativada. Um nicho foi criada para acomodar um sistema elétrico e permitir o movimento livre de uma pálpebra fina confeccionada em silicone preso ao sistema. A pálpebra móvel foi confeccionada com silicone de grau médico (SILASTIC® MDX4-4210) e conectada a um sistema elétrico e eletrônico responsável por comandar os movimentos de abertura e fechamento. Este protótipo mecânico e elétrico com o sistema conectado a um sensor capturou com sucesso o movimento das 
pálpebras do olho acústico contralateral. O sistema mecânico e elétrico proposto, fixado a uma prótese oculopalpebral, conseguiu estabelecer e sincronizar os movimentos da pálpebra com o olho sadio. facial.

PALAVRAS-CHAVE: Prótese oculopalpebral. Sistema de movimento da pálpebra. Reabilitação

\section{REFERENCES}

AHMED B, BUT AM, HUSSAIN M, AMIN M, YASDANIE N. Rehabilitation of nose silicone based maxillofacial prosthesis. J of the College of Physicians and Surgeons Pakistan., v. 20, n. 1,p. 65-70, 2010.

ALMEIDA GAS, GOMES NS, Maria Helena BARBOSA MH,BARICHELLO E.Disturbances in sleep patterns of patients undergoing gastrointestinal oncological surgery. Biosci. J., v. 33, n. 2, p. 476-484, Mar./Apr. 2017. https://doi.org/10.14393/BJ-v33n2-34323

ARDUINO. Available at https://www.arduino.cc. Acess in 10/10/2014.

BINDHOO YA, ARUNA U. Rehabilitation of na Orbital Defect: A Case Report. J Indian Prosthodont Soc., v. 11, n. 4,p. 258-264,2011. https://doi.org/10.1007/s13191-011-0093-6

BRACHA V, NILAWEERA W, ZENITSKY G, IRWIN K. Video recording system for the of eyelid movements during classical conditioning of the eyeblink response in the rabbit. J Neurosci Methods., v. 125, n. 1-2, p. 173-181, 2003. https://doi.org/10.1016/S0165-0270(03)00053-0

BULLING A, WARD JA, GELLERSEN H, TROSTER G. Eye movement analysis for activity using eletrooculagraphy. IEEE Trans Pattern Anal MachIntell., v. 33, n. 4,p. 741-753, 2011.

https://doi.org/10.1109/TPAMI.2010.86

CASTRO FL. Class I infrared eye blinking detector. Sensors and Actuators A.,v.148,n.2,p.388-394, 2008. https://doi.org/10.1016/j.sna.2008.09.005

CESAR CPHAR, SILVA K, PARANHOS LR, BALDRIGHI SEZM. Quality of life of subjects with and without nose breathing difficulties. Biosci. J., v. 32, n. 1, p. 272-278, Jan./Feb. 2016.

https://doi.org/10.14393/BJ-v32n1a2016-31149

CHAU M, BETKE M. Real time eye tracking and blink detection with usb cameras. Boston University Computer Science Technical Report.,v. 12, n. 1, p. 1-10,2005.

GU JJ, MENG M, COOK A, FAULKNER MG. A study of natural eye movement detection and ocular implant movement control using processed eog sinals. IEE Intern Conference on Robotics Automation., v. 4, n. 1, p. $1-25$.

KONG X, WILSON GA. A new eog-based eyeblink detection algorithm. Spring-Verlag., v. 30, n. 4, p. 713719, 1998.

KONRATH M, GROSKOPF J, MARZELLA B, MUSSER M, CACCIOTORE J. Blinking orbital. Final report. BME., p. 201,2010.

KREITLOW H, KIMMEL R, GASTON J, MCANTON A. Blinking Orbital Prothesis - Final.BME., p. 200, 2008. 
KROLAK A, STRUMILLO P. Eye-blink detection system for human-computer interaction. Universal Acess in the Information Society., v. 11, n. 4, p. 409-419,2012. https://doi.org/10.1007/s10209-011-0256-6

Orlowska-Majdak M, Kolodziesjski P, Dolecki K, Traczyk WZ. Application of infrared detection in the recording of eyelid movements in rabbits. Acta Neurobiol., v. 61, n. 2, p.143-151,2001.

PARK I, AHN J-H, BYUN H. Efficient measurement of eye blinking under various illumination conditions for drowsiness detection systems. IEE Computer Society., v.1, n. 1, p. 383-386, 2006.

ROUMANAS ED, FREYMILLER EG, CHANG TL. Implant-retained protheses for facial defects: an up to 14year follow-up report on the survival of implants at UCLA. Int J Prosthodont., v. 15, n. 1, p. 325-332,2002.

RYANA SB, DETWEILER KL, HOLAND KH, HORDA MA. Long-range, wide field-of-view infrared eyeblink detector. Neuroscience Methods., v. 152, n. 1, p. 74-82, 2006. 